\title{
Comics and the Slaughterhouse: Alberto Breccia and the Neighbourhood of Mataderos
}

DOI:

10.1386/jucs.5.3.281_1

\section{Document Version}

Accepted author manuscript

Link to publication record in Manchester Research Explorer

\section{Citation for published version (APA):}

Scorer, J. (2018). Comics and the Slaughterhouse: Alberto Breccia and the Neighbourhood of Mataderos. Journal of Urban Cultural Studies, 5(3), 281-297. https://doi.org/10.1386/jucs.5.3.281_1

\section{Published in:}

Journal of Urban Cultural Studies

\section{Citing this paper}

Please note that where the full-text provided on Manchester Research Explorer is the Author Accepted Manuscript or Proof version this may differ from the final Published version. If citing, it is advised that you check and use the publisher's definitive version.

\section{General rights}

Copyright and moral rights for the publications made accessible in the Research Explorer are retained by the authors and/or other copyright owners and it is a condition of accessing publications that users recognise and abide by the legal requirements associated with these rights.

\section{Takedown policy}

If you believe that this document breaches copyright please refer to the University of Manchester's Takedown Procedures [http://man.ac.uk/04Y6Bo] or contact uml.scholarlycommunications@manchester.ac.uk providing relevant details, so we can investigate your claim.

\section{OPEN ACCESS}




\section{Mataderos}

At the intersection of Avenida Juan Bautista Alberdi and Guardia Nacional in the neighbourhood of Mataderos in Buenos Aires, there is a mural dating from 2013 that celebrates the comics artist Alberto Breccia (1919-1993) [Fig. 1]. In two recesses, which appear to be bricked-up windows, the passerby can see, on one side, a portrait of Breccia drawn by his son Enrique and, on the other, an image taken from Breccia's 1969 version of the classic work El eternauta. 'Above the two images is the slogan 'Unidos y organizados' [United and Organized] and below "'El creador y sus sueños" Alberto Breccia 1919-1993 Amigos, Familiares y Vecinos' ['The Creator and His Dreams' Alberto Breccia 1919-1993 Friends, Family and Neighbours]. ${ }^{2}$ A few blocks further down this major thoroughfare, outside the iconic Cedrón pizzeria and on the same corner as a statue of the boxing champion Justo Suárez, another of Mataderos' famous residents, there is a 1994 plaque suggesting that the corner be named after Breccia (called here the 'padre de la historieta' [father of the comic]). Screwed into the marble plaque is a brief poem about Breccia's work and his love of Mataderos with the note 'Homage from his Neighbourhood'. ${ }^{3}$

The first thing these memorials highlight is that Alberto Breccia, one of Latin America's most important comics artists, had a very close relationship to the neighbourhood where he grew up in the 1920s and 1930s, even though he was in fact born in Montevideo, Uruguay. They also lend Breccia and his work a concrete material presence in Mataderos, reminders of his ongoing biographical connections to the neighbourhood and of the affection with which he is held there. But there is a third, less immediate but equally important, link to be drawn: above the aforementioned mural is a stone that shows this building to be the original site of "'La Hispano Argentina" Curtiembre y Charolería Soc. Anon.'. Originally founded in the nineteenth century by Spanish immigrants, the main factory of La Hispano Argentina is now located elsewhere. But the building in Mataderos is still connected to the tannery, housing the 'Mutualidad del Personal de la Curtiembre La

\footnotetext{
${ }^{1}$ The first version of this most famous of Argentine comics, which was published between 1957 and 1959, was written by Héctor Germán Oesterheld and drawn by Francisco Solano López. Oesterheld revised the text for the version with Breccia's drawings, a publication that had an ill-fated run in the magazine Gente.

2 All translations from the Spanish, unless otherwise indicated, are mine.

${ }^{3}$ These sites formed part of a walking tour of Mataderos organized by Pablo Turnes as part of the project 'Comics and the Latin American City' funded by The Leverhulme Trust (https://comicsandthelatinamericancity.wordpress.com/maps/).
} 
Hispano Argentina', the mutual benefit society for the company's workers. The building is, therefore, a reminder of the long-standing ties between this part of the city and the meat-packing industry (Mataderos in Spanish means slaughterhouse).

Mataderos has often been seen as a frontier space that locates the grasslands of the pampas within the city, a liminality that places it at the crux of the long-standing Argentine trope of civilisation versus barbarism, the dichotomy set out by Domingo Faustino Sarmiento in the nineteenth century which presented the city as the site of European-driven culture and enlightenment, and the interior as provincially backward and barbaric. Integral to Argentina's meat industry, one of the nation's most lucrative and certainly most symbolic products, Mataderos has also long been a traditionally working-class urban district, later becoming a stronghold for leftwing Peronism, the populist ideology that has dominated Argentine politics ever since the first presidency of Juan Domingo Perón (1946-1955). Breccia himself had been part of the meat industry, working for a while in his father's carcass-gutting business and once suggesting that he took up drawing precisely to escape that profession. That the mural commemorating Breccia is located on this particular building, therefore, is a fitting reminder of the way his work is intertwined with the meat industry and the labour that underpinned it.

In this article, I explore the way that Breccia uses comics, another form of salaried labour, to engage with the history of Mataderos. I focus on two of his comics set in the neighbourhood: Un tal Daneri and 'El aire'. The eight stories that make up the series Un tal Daneri were written by Carlos Trillo and drawn by Breccia between 1974 and 1977. ${ }^{4}$ They relate a number of cases connected to a private detective, Daneri: in one episode a woman pays him to look after the son she prophesizes will shortly be killed; in another he tries and fails to help a friend being hunted down by a local gang; and in another he tries to settle the score between a piano-player (by breaking his fingers) and his model girlfriend (by punching her in the face). The short-story 'El aire', written by Guillermo Saccomanno, who also grew up in Mataderos, was first published in 1976 in the Italian magazine Linus, before being published in Spanish the following year. The story shows how the protagonist Marturano, released from prison after two decades following an armed robbery, returns to Mataderos to visit Delia, his former partner who was seemingly responsible for his capture. Mistakenly believing he is returning to take his revenge, the police shoot him dead at Delia's house.

\footnotetext{
${ }^{4}$ The comic was published in several different magazines and books between 1974 and 1978, not appearing as a complete collection until 2003 (Berone, 2014: 61).
} 
These comics are set in cities rife with violence. That is unsurprising given that they were written within one of the most tumultuous periods in recent Argentine history, from just after the death of President Juan Domingo Perón in July 1974, until the early years of the brutal military dictatorship that came to power in 1976 and which was responsible for the slaughter of some 30,000 Argentine citizens, not to mention the torture of innumerable others. Carlos Trillo himself made an explicit connection between Un tal Daneri and the political violence of the period: 'The Triple A was emerging at the same time as Daneri [...]. He was a tough guy, perhaps dating back to previous military governments, perhaps to the first Peronist era. Perhaps, we thought, he was a cop removed by force for beating someone to death. He's not much of a detective, more a tough guy with a kind of morals. Something like that' (cited in García, 2003). ${ }^{5}$ The political violence of the period is intensified in Mataderos because of its historic ties to the violence of the slaughter industry.

Yet Mataderos not only speaks of the material practice of animal slaughter but also of the slaughterhouse's political symbolism, itself powerfully inscribed in the Argentine cultural imagination. ${ }^{6}$ In his reflections on the trope of the slaughterhouse in Latin American cultural production, Gabriel Giorgi describes the slaughterhouse as 'that zone, universe or territory which is marked out around the death of the animal and the transformation of a "body" into "flesh"' (2014: 129). He argues that the figure of the animal can reveal the manner in which, under modernity, bodies are deemed worthy or not of protection, such that the animal becomes closely tied to the figure Giorgio Agamben called homo sacer (2014: 18-23). In the second half of the twentieth century, Giorgi suggests, cultural production in Latin America has often reflected on the growing contiguity between human and animal life and he suggests that in the works he analyses (including texts by Clarice Lispector, Carlos Busqued and Osvaldo Lamborghini and Martín Kohan) the distinction between person/non-person is disrupted: 'These are texts in

\footnotetext{
${ }^{5}$ The Triple A or Alianza Anticomunista Argentina (Argentina Anticommunist Alliance) was a far-right organisation that ran death squads in the years preceding the 1976 military coup.

${ }^{6}$ Perhaps the most famous cultural representation of the slaughterhouse in Argentine culture is Esteban Echeverría's story El matadero, which depicted the violent brutality of supporters of the nineteenth-century dictator Juan Manuel de Rosas. Echeverría's text was famously adapted to comic form by Enrique Breccia as part of the series edited by Ricardo Piglia entitled La Argentina en Pedazos, in which seminal works of Argentine literature were turned into comics. Echeverría's text was also adapted in another comic version drawn by Juan Soto that appeared in the Picado Grueso supplement of Fierro: La historieta argentina (\#20, 2008). Other examples of artists who have used the slaughterhouse to explore Argentine history include Carlos Alonso and Paula Luttringer.
} 
which the normative distinction - modern and civilising - between the human and the animal is displaced by lines of continuity, contiguity, landscape and ambivilence between human and animal bodies' (2014: 29). As a result they highlight how 'all firm and stable distinctions between human/animal is replaced by the more unstable and political distinction between bios/zoé, between protected and dispensible life: cultural slaughterhouses emerge out of that displacement and that tension' (2014: 137). In urban terms, Giorgi's comments evoke the eruption of the animal within the city and more precisely the manner in which the preconfigured processes and 'calculated trajectories' of the biopolitical, capitalist city are disrupted by 'the animal of the street, the animal in the street' (2014: 235-236).

Here, I will look at how Breccia's work depicts Mataderos as a site where human, animal and non-human fuse together, perhaps offering an alternative to the aforementioned dichotomy of the civilized and the barbaric, which can be used to present certain parts of the city or sectors of society as uncivilized, threatening and thus necessary to control. I argue that the highly material, embodied techniques that Breccia uses, including cuts with blades, paper tears and collage, force us to reflect on how body, animal, culture and the mechanical are intertwined. Reading Breccia's work in this way reminds us of how artistic practice can be used to embody the materiality of marginal bodies and spaces, both of which are subject to the visual politics that order and control urban life and its accompanying imaginaries.

\section{Mataderos: The Material and the Animal}

The ongoing link between comics and the neighbourhood of Mataderos was recently demonstrated in the comic Malandras (2014), written by Randolfo Santullo and drawn by Dante Ginevra, and which originally ran between 2010 and 2011 in the magazine Fierro. The comic interweaves a localised power struggle between Italian and Russian immigrant gangster groups based in the neighbourhood together with the national political situation in Argentina in 1955 - specifically the plot against president Juan Domingo Perón that eventually led to his removal from power. Noteworthy for its depiction of 16 June 1955, the day when navy planes bombed their own citizens in the Plaza de Mayo as part of the coup against Perón, the authors also capture the cityscape of Mataderos at a key point in its own political history, incorporating period details such as cobbled streets, tram rails that have been superseded by local buses, tango musicians in bars, and knife fights. 
But Santullo and Ginevra also take the opportunity to pay homage to Alberto Breccia as part of their study of Mataderos, including him in a cameo role that indicates both his importance within the Argentine comics canon and also the way he is associated with this particular part of Buenos Aires. In the episode 'Una noche cualquiera' Breccia is seen visiting a brothel where he relates to a prostitute his dreams of becoming a comic artist, tracing in the air images of several of his famous characters [Fig. 2]. Far from being the hands of a draughtsman, however, they are visibly scarred as a result of his work in the slaughterhouse. In fact, these scars are the only visible and evident trace of the slaughterhouse in the entire work. But in that one panel we are reminded of the ineradicable trace of the labour practices that even Breccia could not escape. It highlights Breccia's embodied artistic techniques, the way that the slaughterhouse blade is refashioned into an artist's tool. And it captures the material manifestations of the striations, cuts and wounds that make up a labour practice - and a neighbourhood - haunted by the animal.

Inhabitants of Buenos Aires have historically shaped their identities around the neighbourhoods in which they live. Nevertheless, prevailing imaginaries of Buenos Aires often ignore more marginal neighbourhoods, like Mataderos, even when they are nonetheless integral to the history of the city. As the writer Juan Diego Incardona, who has built much of his fictional output around another neighbourhood in the city - Villa Celina -, suggested in a radio interview: 'I always think that the neighborhood can tell the history of the country, and the country can't tell the history of the neighborhood' (Lavaca, 2009). His comments are especially relevant to the case of Alberto Breccia, an artist inherently linked to Mataderos despite being Uruguayan. ${ }^{7}$

Drawing on Jorge Luis Borges' writings set on the urban periphery of Buenos Aires, Beatriz Sarlo has argued that these parts of the city threaten the visual coherence of the urban landscape. It is, she writes, a place 'where the urban does not stabilise, its interior limit always harassed by the non-urban, which is not countryside but dirt, decay, degradation; in the suburbs smells and materials seep into each other and mix, the plots that survive whither, and buildings are always on the verge of aging prematurely' (2009: 78). Barring its once-a-week market, itself a somewhat stylised vision of what constitutes 'the countryside', Mataderos is neither wealthy enough nor exceptional enough to be consumable in any other way than as a symbol of the past, a barrio lost in time and space. ${ }^{8}$

\footnotetext{
${ }^{7}$ Pablo Turnes notes that Breccia never changed his nationality and thus never voted in Argentine elections (2015: 31).

${ }^{8}$ The sense that Mataderos symbolises the-country-in-the-city persists. The imaginary of the gauchos, the cowboys of the rural interior, can still be found at the Feria de Mataderos, a
} 
Mataderos was established at the turn of the twentieth century following the move of the municipal slaughterhouse from its previous location in what is now the neighbourhood of Parque Patricios. Developing an economy around the diverse businesses that industrialized the animal, the new site was chosen precisely to restore the distance between the slaughterhouse and the expanding city centre. As Giorgi notes, citing Noelie Vialles, 'the history of slaughterhouses [...] is that of their growing reclusion and confinement, until the arrival of meat-packing plants and the contemporary industrial farms that restrict all public visibility to the greatest degree possible' (2014: 131). ${ }^{9}$ Mataderos was right at the edges of the city, just inside the recent marking out of the Avenida General Paz ring road, which delimited the inside of the city from the out. It was, as one journalist put it, 'finis terrae', or, in the words of another, the 'Pampa del Asfalto' [Countryside of Asphalt] (cited in Cutolo, 1998: 519).

Mataderos quickly became integral to many national disputes, not least Lisandro de la Torre's attack on the government in the mid-1930s for the state of the meat industry and the ongoing complicity with British neocolonial economic expansion. ${ }^{10}$ The ties between Mataderos and national politics intensified in the 1940s and 1950s, during which period the neighbourhood benefitted from social housing projects and improved worker legislation. ${ }^{11}$ Following Perón's exile in 1955, however, President Arturo Frondizi decided to privatise the Frigorífico Nacional [National Meat Processing Plant], which had been inaugurated in 1923 to function as a benchmark against which the meat industry, and particularly the earnings of foreign-owned companies, could be compared (Salas, 1990: 24). The violent suppression of the resultant 1959 strike brought about a general strike, not just as a sign of solidarity against the use of riot police and Sherman tanks (Salas, 1990: 178), or as a protest against the sale of national property, but

\footnotetext{
craft and food market inaugurated in 1986 and held in the square and streets around the old market buildings and which draws in crowds of locals and tourists every weekend.

9 The historian Osvaldo Pérez suggested that between 1580 and the mid-1990s the slaughterhouse moved some $13 \mathrm{~km}$ from the Plaza de Mayo at an average distance of $31 \mathrm{~m}$ per year (1995: 91), a symbolic way of demonstrating how the city constantly tries to push the site of slaughter beyond its limits.

${ }^{10}$ According to Cutolo, de la Torre was a founding member of an intellectual group that used to meet in the Mercado Nacional de Hacienda in Mataderos after 1922 and which included, among other figures, the folkloric songwriter Atahualpa Yupanqui and Edmundo Kelly, the so-called 'Irish Gaucho', who administered the market (Cutolo, 1998: 545).

${ }^{11}$ The residential social housing project Barrio 'Los Perales' was built in 1949, a complex for some 5,000 residents that was part of the housing scheme named after Eva Perón and which was funded by the Banco Hipotecario Nacional (Cosacov et al., 2011: 40).
} 
also because it became a flashpoint around which the resistencia peronista [Peronist resistance], the network of increasingly militant and often fractured Peronist groups that were set up after 1955 with the aim of returning Perón to power, could coalesce (Salas, 1990: 85). ${ }^{12}$

Giorgi has highlighted how Peronism in its various guises has often been presented as an animalistic threat to civilised humanity, a humanity that, in turn, when faced with 'the animal, the monster, the barbarian, the Indian, etc. [...], justifies all forms of violence' (2014: 176). The violent repression of the 1959 strike in Mataderos reflects that perception of Peronist supporters as being uncivilized and in need of domestication. Because of its links to both the animal and the industrial, to national economics and workers' rights, and to a product - meat - that lies at the heart of the Argentine imaginary, then, Mataderos becomes a zone that blurs the boundaries between various social and political boundaries and, ultimately, between the dichotomies of civilization and barbarism. The machines of modern capital, located in the city, itself the machine of modern capital, is nonetheless dependent on the stream of alive-to-dead bodies that pass through. It is this history of the neighbourhood, one of the animal in the city, of urban marginalities, and of a strong working-class culture based around the meat-packing industry, that is the backdrop to another labour practice: Alberto Breccia's comics of Mataderos.

\section{Mataderos in Un tal Daneri and 'El aire'}

In an oft-cited interview published in 1980 Breccia noted how Mataderos had marked his childhood and how integral it was to Un tal Daneri:

I was a poor kid, from Mataderos. My old man had a gutting business and I started drawing so I wouldn't end up an offal butcher, which is a pretty trashy job. Mataderos was a neighbourhood that really got inside me. I think that something of what I saw in those early years of my life came out in Un tal Daneri. Those brick walls, those streets of mud, those clouds that are so low they seem to be within reach. In Mataderos I saw two old-fashioned duels involving Pampa Julio, an Indian prince who'd

\footnotetext{
${ }^{12}$ The Peronist ties to Mataderos would be made further evident in July 1972 in the Estadio Nuevo Chicago, the home ground of the barrio's football club. Some 20,000 Peronist supporters, largely comprised of the youth wing, the Juventud Peronista, came to the stadium in defiance of the military government's state of siege. The event was the first that took place under the slogan 'Lucha y vuelve' [Struggle and Return], the notion that Peronism had to return to the streets to enable the return of Perón (Bonasso, 1997: 254-256).
} 
become a big shot. One of those duels, I remember, was fought only with the flat of the blade, and they sliced each other up bit by bit. Yes, that was the Mataderos of Daneri. (Trillo and Saccomanno, 1980: 148)

Breccia's comments on Mataderos could equally be applied to 'El aire', which mentions Mataderos by name on the first page. The first frame of 'El aire' depicts Marturano being released from jail. Far from emerging from darkness into light, however, he emerges from the white doorway of the jail into the black expanse of the city (19). The city is full of oppressive shadows and silhouettes, mirroring Argentina's dark political landscape and Maturano's observation that his years in prison were 'twenty long years, made up of the same grey days', a veiled reference perhaps to post-Peronist Argentina. But even at the time of his capture Argentina was far from being idyllic. In one frame he is seen being tortured by mysterious, diabolic figures. In that sense, things have not changed much in Mataderos, since the shady figures of the state continue to operate in the neighbourhood. The image suggests a clear link between this earlier period in the history of the city and the time the comic was written, by which point it was clear that the state was using torture in an even more systematic and widespread fashion. The civil conflict between state and citizen represents a country that is divided, split between political factions and being ripped apart by illicit kidnappings, torture and disappearance. For that reason, Maturano notes that the air of the neighbourhood has not changed: 'The same acidic smell, a rotting smell' (21). That smell of the slaughterhouse provides a further symbolic link to the political violence that is taking place in the neighbourhood.

Both texts, therefore, highlight how the setting of Mataderos creates a palimpsestic history of violence. In the first instance, as the home to the slaughterhouse, Mataderos is the space where the animal from the country is made subject to the violent machine of urban capital. This element, more implied than explicit, fits with one of the two overarching trends that Giorgi (2014) sees in what he calls the 'mataderos de la cultura' [cultural slaughterhouses]. Giorgi argues that many of contemporary Latin American works explore the relationship between bodies and modern capitalism, such that exploited workers' bodies are affiliated to the dead animal carcasses that are sold as commodities by the violent death machine of capitalism (2014: 134-135). The link to those texts that Giorgi (2014: 132-133) sees as exploring the slaughterhouse as a space where sovereign power is revealed as animal precisely via acts of bloody violence that destroy men as if they were beasts is even more explicit in Breccia's comics. The references in the comic to the para-state violence of the 1950s and 1970s create a direct tie to the animalistic violence of power. As Daneri says to the gangster leader El 
bagre in the eponymous episode when he kills a man with no weapon: 'He was unarmed, you animal!', an accusation that fits with the leader's name, a reference to the catfish that feed at the bottom of murky waters. And there is a further layer of violence, one referred to by Breccia in the quote cited above and that relates to the fact that the neighbourhood is a frontier space that continues to be shaped by the legacy of knife fights, native Indian populations and codes of honour.

Pablo Turnes, in a very insightful reading of Un tal Daneri, has highlighted how long-standing codes of honour infiltrate the actions of the characters (2015: 190). He notes how Daneri is an anti-hero located precariously between state authority and criminality, symbolising the history of corruption and violence within the Argentine state, not least at a time when para-state death squads were operating within Buenos Aires (2015: 191). Turnes analyses the episode entitled 'Ojo por ojo', in which Daneri disfigures a film star after she tricks him into breaking the fingers of her piano-playing former partner, as precisely a savage act of pre-state revenge (2015: 193). It is Daneri who crosses the urban abyss that separates the piano player, who plays Homero Manzi's tango 'Sur', a song about lost love in the peripheral neighbourhoods of Buenos Aires, from the film star, who lives in a new highrise apartment block in Belgrano. The architectural style of her residence symbolises the growth of an increasingly affluent urban middle class during this period. Laura Podalsky suggests that these 'modern skyscrapers and innovative buildings brokered Argentina's break from the Peronist past and reentry into the world market' (2004: 17). Breccia exaggerates those links to global markets by using a photograph of the Alcoa Building in Pittsburgh for the building. ${ }^{13}$ As Turnes says, Un tal Daneri confronts us with an act of displacement that presents the city as 'the only space where social life is possible' but which locates Daneri 'in that limit where the city confronts its edges and, at the same time, goes beyond them; where the old codes and everyday dramas find an extreme, fatal abundance of flesh' (2015: 196-197).

The same atmosphere of revenge haunts 'El aire', where the spilling of blood returns in cyclical fashion. As the narrator states, 'Just like twenty years ago, he calls at that door, the same door' (22). The variation here, however, is that Maturano is not returning to his former lover to seek revenge but, despite expectations, to tell her that he still loves her. When he raises his hands to embrace her, the hidden policeman shoots him. The policeman's concluding thought, that 'guys like him always want revenge' is revealed to us (and Delia) as being untrue. It is here the figure of the state, the body that is seen to be

${ }^{13}$ The Alcoa Building, which was built as the 30-storey headquarters of the Aluminum Company of America (ALCOA), was completed in 1953. 
engaging in acts of torture, that returns to administer a false, misplaced justice. The story concludes: 'The air of Mataderos smells rotten. A pervasive plague that impregnates everything: the tiles covered with blood and even that siren that you can now hear throughout the neighbourhood' (24). Here the imposition of an act of apparent justice by the state turns out to be based on a false assumption of an inevitable desire for revenge. As a result, Mataderos, here symbolised by Maturano, cannot escape its association with a past dependent on codes of revenge since the state does not allow him to do so. It is the state that expands the spilling of blood beyond the confines of the slaughterhouse.

It is not just the textual or visual narrative that creates meaning in these two works, however, but also the very materiality of Breccia's artwork, not least his highly textured use of collage. Even though 'through the mechanical process of reproduction, the tactility of collage is lost in the smoothness of the printed page', as Rommens and Turnes argue, 'what matters is that it is there as memory trace, testifying to the irreducible materiality of its being' (2014: 38). In 'Cara marcada', the first episode of Un tal Daneri, for example, Breccia uses a range of artistic techniques to create that visual materiality, deploying shading, block shapes in both black and white, paper cuts, blurred imagery, photographs and broader brushstrokes to render the characters and the built environment. Such embodied techniques highlight the interactions between author, page and city. In the final frame, which depicts Daneri walking away down a Mataderos street, the precision of the brickwork on the left-hand wall contrasts with the lines scored in the ink to mark out the cobbles on the pavement [Fig. 3]. At the same time, brushstrokes capture the presumably muddy street as the rain falls from a cloudy sky. The materiality of the landscape is matched by the highly textured depiction of the old woman whose wrinkled face dominates the first three panels.

Breccia's use of collage is famous, part of his artistic transformation that started to take place at the end of the 1950s and which is evident in his most well-known works. Breccia's technique, which Laura Vazquez links to the contemporaneous Juanito Laguna collages by the artist Antonio Berni (2010: 120), together with his painterly style, no doubt one reason why his work came to the attention of the art critic Oscar Masotta, who famously curated an exhibition entitled 'La historieta mundial' [The world comic] in the Instituto Di Tella in 1968. In his early reading of Breccia's style, in which he also pointed out that the contrast between cinematographic images and Breccia's drawings serves to highlight the importance of the latter (1970: 159), Masotta argued that the ultimate value of a comic is the degree to which it shows the language itself of comics, something evident in the work of Breccia, who, he 
says, does not so much represent horror as 'represent the way of representing it' (1970: 158). I would suggest that the materiality of Breccia's images of Mataderos intervenes in an even wider set of political and urban textures.

At the time these comics were being created, Mataderos was continuing to be sliced up, not just by the political landscape of 1970s Argentina, but also by the socio-economic transformations of industrialisation and privatisation. In 'El aire', which is heavily reliant on a style of collage and the use of paper variously sliced or ripped by hand, blocks of black or white are set alongside photographs, such that the work moves between the documentary trace and layers of abstract fictionality. The precision of the scissor contrasts with the brute unpredictability of the rip, which adds depth and texture and which serves as a reminder of the way that the city itself is here increasingly comprised of ripped forms. Thus, though Maturano does suggest that much has stayed the same in Mataderos, his initial reaction is the neighbourhood is actually quite different: 'After twenty years, everything's changed. Except the trees. They're still the same' (20). The factory chimneys were evident before his arrest, shapes outlined by the moonlight but now they appear in a photograph, smoke billowing [Fig. 4]. In the final panel of the story, entirely comprised of ripped and cut paper, the chimneys and their smoke dominate this fragmented cityscape [Fig. 5]. 'El aire', therefore, captures very clearly the manner in which, by the time of the dictatorship, industrial expansion went hand-in-hand with state violence. Breccia's artwork, which, through its paper cuts and tears, retains a sense of physical labour, is perhaps an attempt to retain a trace of the manual labour practices and the working bodies that shaped Mataderos. Just as they were being fragmented and erased, Breccia crafts an imaginary out of those fragments and acts of violence.

Comics here, then, not only captures the grid-like structure of the urban fabric, the grid that precisely cut up the pampas and which was projected onto them even before such streets were actually built (Gorelik, 1998), but also contains within that grid a series of internal fractures. The rational order of the grid-pattern is here revealed to contain within it the unpredictable shapes of torn paper and physical slices into the page. The ciudad letrada, the notion of a city of lettered figures as a fundamental driving force behind the settlement and ordering of the Spanish colonies of the New World and which Ángel Rama (1996) argued went hand-in-hand with the establishment of the urban grid pattern in the Americas, is here disrupted, and doubly so if we remember that this gesture is taking place within a comic, a text itself that disrupts the elite literacy of the lettered city. 
The name of the protagonist of Un tal Daneri is telling, a reference to Jorge Luis Borges' 1949 short-story 'El Aleph' in which the character Daneri tells of a point in a basement where you can see 'all the places of the world, seen from every angle' (Borges, 1996: 623). Alongside this sense of a mythic, universal place, however, the story is also hyper-local. Borges deliberately references specific buildings and streets. He also includes references to the impact of urban modernisation and development in the shape of towerblocks supplied with 'telephones, telegraphs, phonographs, radiotelephony machines, cinematographic equipment, magic lanterns, glossaries, timetables, records, reports' (Borges, 1996: 618). Indeed, one way of reading 'El Aleph' is as a critique of urban modernisation and development; to make way for these hypermodern skyscrapers equipped with the latest technology, the house where Daneri says the Aleph is located, at Garay and Irigoyen, is due to be demolished.

In the face of a rapidly modernizing city, Borges turned to the suburbs in an attempt to hold on to a more familiar urban imaginary. Breccia takes up Borges precisely to explore the (in)stabilities of the relationship between urban centre and periphery and between overarching urban imaginaries and those of the barrio. García is right, then, to highlight that 'Daneri's space is the arrabal [urban fringes]. Nostalgic and poetic. [...] Primitive frontier between dream and myth, the fantastic and the everyday' (2003). In interview, Breccia himself noted that the three stories by Borges that he would like to draw were 'Sur', 'La muerte' and 'El hombre de la esquina rosada' since 'the three speak of the Buenos Aires arrabal, the working-class neighbourhoods', making a specific link between Borges' interest in 'el tango, los duelos, las venganzas y todo eso que tanto le gustaba' and the Mataderos of his own childhood where you could find 'the butchers, the abattoirs, and livestock slaughterhouses' (Vanini, 2016: 215). But, unlike Borges' frontier space, which is pushed at arm's length from the present by a temporal displacement of some 30 or 40 years, in Un tal Daneri and 'El aire' the frontier past and the present of para-state violence and industrialisation are contiguous, sitting alongside each other not just frame-by-frame but also within individual frames.

Un tal Daneri includes many gestures that point simultaneously to the past and the contemporary moment. In 'El monstruo' the house on the edge of the city is tied to the history of the urban fringes both via a citation of Borges ('man's imagination, in terms of monsters, is limited') and the final frame, with its huge open sky that harks back to a city prior to an increase in the height of buildings. These images are also off set, however, by the daughter 
wearing a miniskirt, a symbol of the 1960s. In 'El duelo', the images of horses, mate, knives and single story houses, are countered by the patterns and shapes that are inserted into the images and which come from the technical world of graphic design [Fig. 6]. Breccia's collages of shapes and textures include the use of a knife (the pre-modern) with photographs (the modern). He blends images of bricks, corrugated iron, Citroen $3 \mathrm{CV}$ s and the graffiti 'Para la libertad del pueblo' [For the freedom of the people], all of which locate the action within urban modernization, together with mythic witch-like figures with crystal balls and knife-fights of the past. Thus, Turnes' observation that Breccia's collage style captures the fragmentary nature of memory (2015: 190), should be supplemented by the recognition that such a practice is simultaneously an engagement with an increasingly fragmented present.

The use of collage gives Breccia the visual means to critique that present and its own visual discourse of modernization and technological development. Collage allows Breccia to construct a visual critique that often functions beyond or alongside narrative. Groensteen argues that 'certain mangas are signaled by a massive use of panels that are superfluous from a strictly narrative point of view, their precise function is elsewhere: decorative, documentary, rhythmic, or poetic, whatever the case' (2007: 116). Breccia's panels are rarely entirely superfluous from a narrative point of view. But his use of collage produces backgrounds and foregrounds that not only create what Groensteen calls a relationship of 'co-reference' on the page but that also communicate a visual critique that runs parallel to narrative.

Rommens and Turnes have suggested that 'collage is the technique par excellence to give plastic form to the pathos between randomness and systematic order', noting that the 'grid-layout of comics' means that Breccia's inclusion of chance within panels still takes place within a certain structure. They highlight the 'antinomy between spontaneity and conscious intervention, between the negentropic as the tendency to re-impose order and meaning onto non-sense' (36). That juxtaposition lies at the heart of Breccia's critique of urban life. His images of neon streetlights and advertisements, which belong to a world of fashion and wealth, are offset by highly artistic drawings. In 'Ojo por ojo', for example, the promise of consumption in the shape of fashion magazines, shops and modern apartment blocks is in tension with broken loyalties and the desire for revenge that manifests itself in Daneri's brutal slicing of the face of a woman model, a sequence that is depicted with a flurry of penstrokes. His images often include hyper-modern graphic design. In 'El duelo', for example, we can see graphic shapes and patterns woven into the urban landscape of 
Mataderos. Far from offering the promise of order through repetition or of development through technology, however, these shapes are destabilized by drawings that provide shades, gradations, texture and even chaos. Mataderos thus offers an alternative force to the narrative of technological progress.

At the time Breccia was working there was a widespread belief in the power of graphic design, industrial design, architecture and urban planning to express an ideology of order and clarity (Silvestri, 2000). As Graciela Silvestri argues in her study of architecture during the 1976-1983 dictatorship, including the graphic design that went into the symbols for the 1978 World Cup, at the time there was a real belief that good design could offer a solution to urban planning problems (2000: 41). Breccia offers his own flipside to that imaginary of urban order and clarity. In the episode 'El Grima', for example, the protagonist takes refuge from a pack of mysterious former associates inside an abandoned factory building, hiding midst a pile of discarded objects including cogs and wheels, we are confronted with a space in ruins. Breccia's collage of fragments, one of which includes a photograph of the factory roof, themselves capture the splintered visual nature of the contemporary city. Daneri's failed attempt to save Grima, who in fact thinks that Daneri has also betrayed him, suggests how this gesture of friendship undone by mistrust is tied to the landscape of industrial decline.

Breccia's drawings, therefore, disrupt the visual legibility of urban capitalism. The way his images move from identifiable block shapes to highly detailed shaded images is unnerving. The use of stains, blotting, shading and detail means that some images are almost illegible in visual terms. His visual critique is also introduced via the use of a razor blade in some images to produce white lines in inked areas, a technique evident in several episodes. Turnes notes in passing that Breccia's use of a razor blade within the artwork links the comic specifically to the knife-fights of the urban periphery and to the practices of the slaughterhouses where Breccia's father worked and from which Breccia wanted to escape. ${ }^{14}$ The link between the slaughterhouse and the use of a razor blade for the comic artwork is crucial, however, and is intensified by Breccia's description of the instrument he used for scraping the cows' intestines: 'you grabbed this cylinder of quebracho wood, which had inserted in it a saw blade [...] with that blade barely sticking out, like those razor blades of nowadays, and you scraped it, slowly, emptying the gut' (cited in Sasturain, 2013: 22). For all his comments about wanting to escape

\footnotetext{
${ }^{14}$ Turnes notes that from Mort Cinder on, a work written by Héctor G. Oesterheld and which dates from the 1960s, 'Breccia started experimenting by dipping a razor blade in ink and tracing cuts in shapes and backgrounds' (2015: 196).
} 
working in the slaughterhouse, which he also described to Juan Sasturain as being 'filthy' (Sasturain, 2013: 21), Breccia, in a work that otherwise writes out the slaughterhouse altogether, cannot draw the city without inscribing it with and through the blade. That is important on the one hand because it reminds us, as Turnes suggests about the use of fingerprints in Mort Cinder, that Breccia's comics are not just what results from labour but that they are the visual and constitutive manifestation of labour (2015: 49). And on the other, because the labour practice itself is inherently tied to a particular sociospatial assemblage and a particular socio-political moment within Buenos Aires. When coupled with his other formal moves - photography, scissor cuts, graphic design - it is evident that the artwork itself is a crossover, a manifestation of the edges, of a cultural form that speaks from but also pushes against the margins.

\section{Conclusion}

Recent scholarship has made clear the different ways in which comics and the city (as well as architecture) are intertwined, whether in terms of the synchronous emergence of comics and the modern metropolis, the way that comics are perceived to be particularly proficient at capturing the multifaceted and multi-sensory nature of urban life, the profoundly spatial form of comics, or the manner in which the grid pattern of the comics page mirrors the grid of many urban settlements or architectural structures (see, for example, Ahrens and Meteling, 2010; Van der Hoorn, 2012; Labio, 2015). In his study of Chris Ware's famous Building Stories, a work that has become an archetypal example of urban comics, Jason Dittmer argues that the 'intersecting temporalities' of Ware's work capture 'urbanism-as-assemblage' (2014: 478). Dittmer argues that such dynamic visions can disrupt our visions of the city by encouraging us to view them in new ways. And in his study of another classic of urban comics, Jason Lutes' Berlin saga, Anthony Enns argues that Lutes presents the city as a multi-temporal archive, a 'collage or montage of intertextual references' (2010: 50). Berlin, he suggests, 'employs the unique characteristics of the comic form to construct a fragmented text that challenges linear narratives of historical continuity' (2010: 58).

Alberto Breccia's comics set in Mataderos, like those of Ware and Lutes, also use the archival assemblage to capture urban multiplicity and encourage the reader to view the city in alternate ways. But Breccia's artwork is quite different to both the more structured grid patterns and flow charts of Ware's work, and also Lutes' meticulously drawn images that construct a city which, in artistic terms at least, is less fragmented than Enns perhaps allows 
precisely because the artwork is so iconically solid, to put it in Groensteen's terms. Breccia's technique instead relies on a more visually diverse collage of images that are themselves traces of photographs and other print publications as well as drawings. Using different artistic techniques he provides a visual reminder of the tactile, material labour process that underpins these images. Through that diversity, Breccia uses comics to create a narrative that both represents a specific place and also embodies the very labour practices that shape that specific urban fabric and the comic itself. That multi-directional practice is Breccia's invitation to view oft-ignored urban neighbourhoods with fresh eyes and a reminder of the power of comics to disrupt dominant visualities. 


\section{Works Cited}

Ahrens, Jörn and Arno Meteling, eds. (2010) Comics and the City: Urban Space in Print, Picture and Sequence. New York and London: Continuum.

Berone, Lucas. (2014) 'La historieta policial en Argentina: De la parodia a la persecución de la prueba'. In: Sebastian Gago, Iván Lomsacov, Roberto von Sprecher, eds. Cuadritos a ras del suelo: La historieta argentina, entre la apuesta por el realismo y los problemas de la representación. Córdoba: Universidad Nacional de Córdoba, pp.59-81.

Bonasso, Miguel. (1997) El Presidente que no fue: Los archivos ocultos del peronismo. Buenos Aires: Planeta.

Borges, Jorge Luis. (1996) 'El Aleph'. In: Obras completas 1. Barcelona: Emecé, pp.617-627.

Breccia, Alberto and Carlos Trillo. (2003) Un tal Daneri. Buenos Aires: Doedytores.

Breccia, Alberto and Guillermo Saccomanno. (2006) 'El aire'. In: Alberto Breccia, Breccia negro versión 2.0. Buenos Aires: Doedytores.

Cosacov, Natalia et al. (2011) 'Barrios al sur: Villa Lugano, Villa Riachuelo, Mataderos, Parque Patricios y Villa Soldati a través del tiempo'. Documentos de Trabajo 56. Buenos Aires: Instituto de Investigaciones Gino Germani, Universidad de Buenos Aires.

Cutolo, Vicente Osvaldo. (1998) Historia de los barrios de Buenos Aires. 2nd edition. Buenos Aires: Editorial Elche.

Dittmer, Jason. (2014) 'Narrating urban assemblages-Chris Ware and Building Stories', Social \& Cultural Geography, 15(5), 477-503.

Echeverría, Esteban. (2006) El matadero; La cautiva. Madrid: Catedra.

Enns, Anthony. (2010) 'The City as Archive in Jason Lutes's Berlin'. In: Jörn Ahrens and Arno Meteling, eds. Comics and the City: Urban Space in Print, Picture and Sequence. New York and London: Continuum, pp.4559.

Ferreiro, Hernán. (2013) Mataderos: Desde Adentro. Buenos Aires: Editorial Dunken.

Fierro: La historieta argentina (2006-2017).

García, Fernando. (2003) 'Trozos argentinos'. In: Carlos Trillo and Alberto Breccia. (2003) Un tal Daneri. Buenos Aires: Doedytores.

Giorgi, Gabriel. (2014) Formas comunes: Animalidad, cultura, biopolítica. Buenos Aires: Eterna Cadencia.

Gorelik, Adrián. (1998) La grilla y el parque: Espacio público y cultura urbana en Buenos Aires, 1887-1936. Buenos Aires: Universidad Nacional de Quilmes. 
Labio, Catherine. (2015) 'The Architecture of Comics'. Critical Inquiry, 312343.

Lavaca. (2009) 'Decí Mu: Letras \& hip hop'. Online: http://lavaca.org/decimu/ 13 deci-mu-territorios-en-resistencia/ [Accessed 15 March 2015].

Masotta, Oscar. (1970) La historieta en el mundo moderno. Buenos Aires: Paidos.

Podalsky, Laura. (2004) Specular City: Transforming Culture, Consumption, and Space in Buenos Aires, 1955-1973. Philadelphia: Temple University Press.

Pérez, Osvaldo. (1995) 'Mataderos de Buenos Aires'. Todo es historia, 339 : 80-92.

Piglia, Ricardo. (1993) La Argentina en pedazos. Buenos Aires: Ediciones de la Urraca.

Rama, Ángel. (1996) The Lettered City. Durham: Duke University Press.

Rommens, Aarnoud and Pablo Turnes. (2014) 'Reinstating the Laws of Chance: Breccia's throw of the dice with Ernesto Sabato's Informe sobre ciegos'. Domínios da Imagem, 8(16), 25-43.

Saccomanno, Guillermo. (1999) El buen dolor. Buenos Aires: Emecé.

Salas, Ernesto. (1990) La resistencia peronista: La toma del frigorífico Lisandro de la Torre. Buenos Aires: Centro Editor de América Latina.

Santullo, Rodolfo and Dante Ginevra. (2014) Malandras. Buenos Aires: Historieteca Editorial.

Sarlo, Beatriz. (2009) La ciudad vista: Mercancías y cultura urbana. Buenos Aires: Siglo XXI.

Sasturain, Juan. (2013) Breccia el Viejo: Conversaciones con Juan Sasturain. Buenos Aires: Colihue.

Silvestri, Graciela (2000). 'Apariencia y verdad: Reflexiones sobre obras, testimonios y documentos de arquitectura producidos durante la dictadura militar en la Argentina'. Block, 5, 38-50.

Trillo, Carlos and Guillermo Saccomanno. (1980) Historieta: Historia de la historieta argentina. Buenos Aires: Ediciones Record.

Turnes, Pablo. (2015) 'La excepción en la regla: La obra historietística de Alberto Brecca (1962-1993)'. PhD Thesis, University of Buenos Aires.

-----. (2015) 'La milonga del destino: Héroes y antihéroes en Un tal Daneri, de Alberto Breccia y Carlos Trillo'. AIC, 15, 189-197.

Van der Hoorn, Mélanie. (2012) Bricks \& Balloons: Architecture in Comic-Strip Form. Rotterdam: 010 Publishers.

Vanini, Alfredo. (2016) Cruce de palabras: Entrevistas y retratos. Lima: Benvenuto Editores.

Vazquez, Laura. (2010) El oficio de las viñetas: La industria de la historieta argentina. Buenos Aires: Paídos. 
Verbitsky, Bernardo. (1970) 'Las apariciones del Negro Astorga'. In: Cuatro historias de Buenos Aires. Buenos Aires: Editorial Rayuela, pp.49-72. 